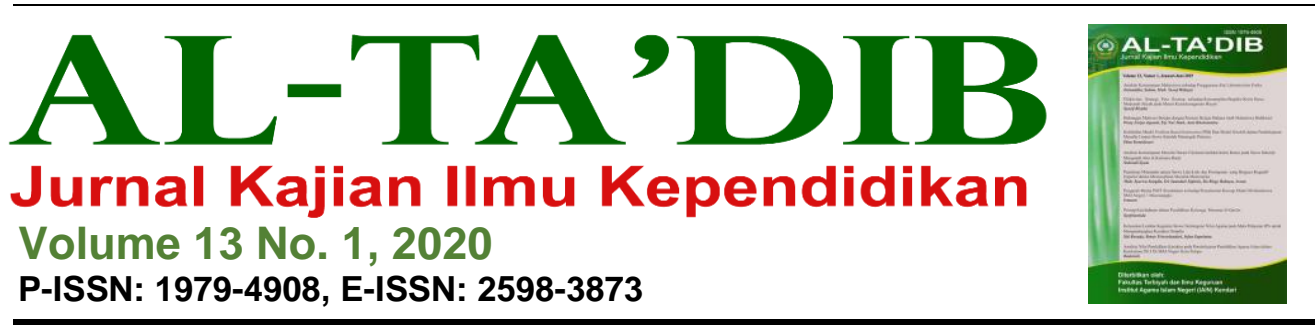

\title{
Analisis Data Miskonsepsi Siswa Sekolah Menengah Pertama dalam Menyelesaikan Operasi Aritmatika Dasar
}

\section{Amanda La Hadi ${ }^{1}$, Dedyrianto ${ }^{2}$}

1 Institut Agama Islam Negeri Kendari, Indonesia. E-mail: amanda.lahadi@gmail.com 2 Institut Agama Islam Negeri Kendari, Indonesia. E-mail: dedyoke1987@ gmail.com

\begin{tabular}{l} 
INFORMASI ARTIKEL \\
\hline Kata Kunci: \\
Analisis data; aritmatika \\
dasar; bilangan bulat; \\
miskonsepsi matematika; \\
pecahan \\
Cara Mensitasi: \\
Hadi, A. L., \& \\
Dedyerianto. (2020). \\
Analisis data miskonsepsi \\
siswa sekolah menengah \\
pertama di Kota Kendari \\
dalam menyelesaikan \\
operasi aritmatika dasar. \\
Al-Tadib, 13(1), 18-33 \\
DoI:
\end{tabular}

\begin{abstract}
ABSTRAK
Studi ini mengungkapkan bagaimana pemahaman siswa tentang aritmatika dasar dan mengidentifikasi miskonsepsi yang terjadi ketika mereka menyelesaikan masalah. Meskipun guru telah menjelaskan prosedur operasi aritmatika dasar pada bilangan cacah, bilangan bulat, dan pecahan sejak sekolah dasar, tetapi masih ada kesalahpahaman konsep di antara siswa. Miskonsepsi ini mayoritas terjadi pada operasi yang melibatkan pecahan. Perbedaan konsep antara apa yang dipahami oleh responden dalam proses belajar mereka dan ilmu pengetahuan telah menghasilkan persepsi yang salah. Dalam artikel ini, penulis menjelaskan analisis kesalahpahaman dalam konsep yang dilakukan siswa pada jenjang sekolah menengah pertama. Penelitian ini adalah penelitian deskriptif yang menggunakan pendekatan kualitatif dan kuantitatif dalam pemberian tes pengetahuan dasar matematika dengan melibatkan 237 siswa kelas 7 dan 8 sebagai peserta di empat sekolah yang berbeda. Penelitian ini menemukan miskonsepsi yang dialami siswa dalam operasi aritmatika dasar yang berupa pengurangan dengan bilangan negatif, penjumlahan dan pengurangan pecahan, dan pembagian pecahan.
\end{abstract}




\begin{tabular}{l} 
ARTICLE INFO \\
\hline Keywords: \\
Algebra; basic \\
mathematical knowledge; \\
data analysis; fraction; \\
integer \\
How to cite: \\
Hadi, A. L., \& \\
Dedyerianto. (2020). \\
Analisis data miskonsepsi \\
siswa sekolah menengah \\
pertama di Kota Kendari \\
dalam menyelesaikan \\
operasi aritmatika dasar. \\
Al-Tadib, 13(1), 18-33 \\
DoI:
\end{tabular}

\begin{abstract}
This study reveals how students' understanding of basic arithmetic and identifies misconceptions that occur when the students solve the problems. Although the teacher has explained the procedure of basic arithmetic operations on whole numbers, integers, and fractions since elementary school, there are still misconceptions among students of junior high school. The majority of these misconceptions occur in operations involving fractions. The difference in concept between what is understood by respondents in their learning process and science has resulted in wrong perceptions. In this article, the author explains the analysis of misconceptions in the concepts made by students at the junior high school level. This research is a descriptive study that uses qualitative and quantitative approaches in providing basic knowledge of mathematics tests by involving 237 in 7th and 8th-grade students as participants in four different schools. This study found misconceptions experienced by students in basic arithmetic operations in the form of subtraction with negative numbers, fraction addition and subtraction, and fraction division.
\end{abstract}

\title{
1. Pendahuluan
}

Seorang guru menginginkan semua siswa dapat membangun kemampuan mengingat kembali (recall) khususnya pada pengetahuan awal tentang operasi perhitungan dasar atau yang dikenal dengan aritmatika (O'Connell \& SanGiovanni, 2011). Kelancaran (fluency) dalam melakukan aritmatika dasar menjadi salah satu pondasi utama dalam mengembangkan literasi numerik seseorang. Kurikulum pendidikan hampir di semua negara telah memasukkan kemampuan ini sebagai kemampuan dasar yang harus dikuasai siswa sebelum mereka menyelesaikan sekolah dasar. Faktanya, masih banyak siswa sekolah menengah yang masih sulit memberikan hasil secara manual untuk perhitungan sederhana seperti $8 \times 7$ atau $48 \div 6$ (O'Connell $\&$ SanGiovanni, 2011).

Selain bilangan bulat, pecahan menjadi salah satu topik aritmatika yang terus menjadi fokus penelitian di berbagai negara (Aliustaoğlu, Tuna \& Biber, 2018; Bailey, Hoard, Nugent \& Geary, 2012; Booth \& Newton, 2012; Hadi, Cahyono \& Kadir, 2017; Philipp, 2000.; Siegler, Duncan, Davis-Kean, Duckworth, Claessens, Engel, Susperreguy \& Chen, 2012). Pemahaman konsep pecahan dan pembagian telah menjadi prediktor terbaik dari kesuksesaan hasil belajar matematika siswa dalam kurun waktu $5-6$ tahun setelah konsep tersebut diajarkan (Siegler, dkk., 2012). Hasil ini telah 
menunjukkan bagaimana siswa pada tingkatan sekolah menengah dan perguruan tinggi memiliki kemampuan yang buruk dalam menyelesaikan masalah-masalah aritmatika dasar (Hadi, Cahyono \& Kadir, 2017; Siegler, Fazio, Bailey \& Zhou, 2013).

Kurikulum pendidikan Indonesia telah memasukkan mata pelajaran matematika sebagai induk dari aritmatika dengan tujuan agar siswa dapat memiliki kemampuan berpikir logis, analitis, sistematis, kritis, dan kreatif, serta mempunyai kemampuan bekerjasama (Kemendikbud, 2013). Akan tetapi, segala proses pembelajaran matematika yang telah dilakukan belum memberikan hasil yang sesuai dengan tujuan ini. Hal ini dibuktikan dengan hasil tes PISA (Programme for International Student Assessment) terbaru yang menunjukkan Indonesia berada pada peringkat 73 dari 79 negara peserta pada tes kemampuan matematika (OECD, 2019). Turun empat peringkat dari pencapaian periode sebelumnya. Hal ini berbanding terbalik dengan sekian banyak penelitian di Indonesia yang memberikan kesimpulan bahwa siswa memiliki peningkatan dalam kemampuan matematika (Deswita \& Kusumah, 2018; Muhsin, Johar \& Nurlaelah, 2013; Priyambodo, 2016).

Kemampuan recall akan terbangun jika pemahaman akan materi tersebut telah terjadi di dalam otak siswa (O’Connell \& SanGiovanni, 2011). Pemahaman ini terbagi menjadi pemahaman prosedural dan konseptual. Pemahaman konseptual terkait bagaimana melakukan sesuatu dan mengapa melakukan hal tersebut, sedangkan pengetahun prosedural terkait pemahaman aturan tanpa alasan (Bush \& Karp, 2013). Guru sekolah menengah beranggapan semua siswa telah menguasai aritmatika-konsep dan prosedur-ketika mereka telah menyelesaikan bangku sekolah dasar. Hal ini bertolak belakang dengan kenyataan bahwa ada siswa yang memiliki kemampuan prosedural yang sangat baik dalam aritmatika, namun sebagian besar dari mereka mengalami kegagalan dalam menjeleskan konsep (Hadi, Cahyono \& Kadir, 2017). Kegagalan ini bisa disebabkan oleh kemampuan siswa yang buruk dalam mengingat fakta sederhana atau kurangnya kemampuan guru untuk mengajarkan fakta tentang konsep aritmatika (Koichu, Harel, \& Manaster, 2013; Siegler, Thompson, \& Schneider, 2011).

Selama beberapa dekade, penekanan utama dalam pembelajaran matematika adalah mempelajari pengetahuan prosedural, atau yang saat ini dikenal dengan kelancaran prosedural (Ghazali \& Zakaria, 2011). Hafalan menjadi aturan dan prasyarat untuk lanjut kemateri matematika berikutnya, dengan sedikit perhatian pada pemahaman konsep. Sementara pemahaman konseplah yang membuat siswa dapat mengaplikasikan pengetahuan yang dimiliki dan memungkinkan dirinya untuk mengadaptasi beberapa ide matematika kedalam situasi yang baru. Hal ini yang menyebabkan siswa pada akhirnya gagal paham dengan konsep-konsep matematika pada jenjang yang lebih tinggi (Bush \& Karp, 2013; Siegler, dkk., 2012). 
Berdasarkan dua jenis pemahaman di atas, kita dapat dapat memandang siswa menjadi tiga golongan. Pertama, siswa yang memiliki pemahaman prosedural aritmatika dengan pemahaman konsep yang baik. Kedua, siswa yang memiliki pemahaman yang buruk dalam keduanya-konseptual dan prosedural. Ketiga, golongan siswa yang hebat dalam prosedural tetapi sama sekali tidak memahami konsep dari operasi yang mereka kerjakan. Siswa kita saat ini mayoritas berada pada golongan kedua dan ketiga (Hadi, Cahyono \& Kadir, 2017). Kesalahan dalam pemahaman konsep yang dilakukan secara berulang-ulang dikenal dengan istilah miskonsepsi (Leinhardt, Stein, \& Zaslavsky, 1990).

Penelitian tentang miskonsepsi aritmatika telah dilakukan di berbagai negara (Aliustaoğlu, dkk., 2018; Bolognese, Fellows, \& Schuhl, 2019; Bush \& Karp, 2013; Dhlamini \& Kibirige, 2014; Ojose, 2015; Vermeulen \& Meyer, 2017), begitu juga di Indonesia (Fuadiah, Suryadi, \& Turmudi, 2016; Herutomo \& Saputro, 2014; Malihatuddarojah \& Prahmana, 2019). Akan tetapi, penelitian yang dilakukan di Indonesia umumnya membahas miskonsepsi yang terjadi pada topik aljabar yang merupakan lanjutan dari aritmatika (Herutomo \& Saputro, 2014; Malihatuddarojah \& Prahmana, 2019). Padahal, pengetahuan tentang miskonsepsi aritmatika sangat dibutuhkan khususnya bagi pengajar matematika agar dapat dijadikan landasan untuk memperbaiki rencana pembelajaran yang akan dijalankan. Selain itu, pengetahun ini juga penting untuk mengantisipasi miskonsepsi pada materi tingkat lanjut (Siegler, dkk., 2012). Oleh karena itu, peneliti tertarik mengkaji lebih dalam tentang miskonsepsi yang terjadi pada siswa dalam topik aritmatika dasar. Fokus penelitian ini pada aritmatika dasar karena dalam kurikulum di Indonesia, pengetahuan tentang konsep ini telah diajarkan sejak kelas 1 SD serta dilanjutkan secara pada kelas 4, 5, dan 6. Akan tetapi, banyak siswa sekolah menengah di Indonesia yang masih memiliki pemahaman konsep yang kurang terkait topik ini (Hadi, Cahyono \& Kadir, 2017). Operasi yang difokuskan disini adalah operasi penjumlahan, pengurangan, perkalian, dan pembagian pada bilangan asli, bilangan bulat dan pecahan. Semua pengetahuan ini merupakan bagian dari pengetahuan dasar matematika (PDM). Sejalan dengan hal tersebut, penelitian ini bertujuan untuk menganalisis miskonsepsi aritmatika siswa sekolah menengah pertama (SMP).

\section{Metode Penelitian}

Penelitian ini adalah penelitian deskriptif yang bertujuan untuk menganilisis secara mendalam tentang miskonsepsi aritmatika dasar siswa SMP. Untuk mendapatkan deskripsi data tersebut, siswa diberi tes pengetahuan dasar matematika berbentuk pilihan ganda sebanyak 30 (tiga puluh) nomor. Data ini digunakan untuk memperoleh data kuantitatif berupa 
skor siswa yang disusun berdasarkan indikator pengetahuan dasar matematika (PDM) yang dikembangkan oleh Kadir (2010) dan dimodifikasi sesuai dengan kebutuhan penelitian. Data tersebut kemudian dideskripsikan secara kuantitatif dan kualitatif berupa persentase pencapaian siswa pada setiap indikator. Lalu, disajikan analisis data miskonsepsi dari subjek penelitian pada butir soal $1-24$ dengan pencapaian kurang dari $45 \%$ yang diperoleh dari data lembar cakaran siswa (pada saat menyelesaikan soal, subjek diminta membuat cakaran dengan menandai setiap nomor soal yang kerjakan). Oleh sebab itu, penelitian ini menggunakan pendekatan kualitatif-kuantitatif.

Penelitian ini dilaksanakan dengan melibatkan partisipan penelitian 237 siswa SMP negeri di Kota Kendari dalam rentang waktu 2015 - 2017. Partisipan berasal dari empat SMP pada wilayah kecamatan berbeda. Instrumen dalam penelitian ini ada dua macam, yaitu instrumen utama dan instrumen bantu. Instrumen utama adalah peneliti sendiri, sedangkan instrumen bantu adalah instrumen tes PDM siswa khusus untuk materi aritmatika. Instrumen PDM yang digunakan dalam penelitian ini terdiri atas dua bagian, yaitu operasi hitung dan matematika terapan. Tujuan diberikan dua jenis soal tersebut adalah untuk melihat pemahaman konsep siswa mulai dari basic problem hingga real world problem sesuai dengan indikator pada tabel dibawah ini.

\section{Tabel 1. Indikator pengetahuan dasar matematika (khusus aritmatika)}

\begin{tabular}{|c|c|c|c|}
\hline \multirow[b]{2}{*}{ No } & \multirow[b]{2}{*}{ Spesifikasi } & \multicolumn{2}{|l|}{ PDM menurut Kurikulum 2013} \\
\hline & & Indikator & $\begin{array}{l}\text { Kelas } \\
(\mathrm{SD})\end{array}$ \\
\hline 1. & Bilangan Asli & Melakukan operasi penjumlahan bilangan asli & \\
\hline 2. & Bilangan Asli & $\begin{array}{l}\text { Melakukan operasi pengurangan bilangan asli } \\
\text { tanpa meminjam }\end{array}$ & II \\
\hline 3. & Bilangan Asli & $\begin{array}{l}\text { Melakukan operasi pengurangan bilangan asli } \\
\text { dengan meminjam }\end{array}$ & \\
\hline 4. & Bilangan Asli & $\begin{array}{l}\text { Melakukan operasi perkalian bilangan asli dengan } \\
\text { faktor pengali satuan }\end{array}$ & II - III \\
\hline 5. & Bilangan Asli & $\begin{array}{l}\text { Melakukan operasi perkalian bilangan asli dengan } \\
\text { faktor pengali puluhan }\end{array}$ & III - V \\
\hline 6. & Bilangan Asli & $\begin{array}{l}\text { Melakukan operasi pembagian bilangan asli } \\
\text { dengan pembagi satuan }\end{array}$ & $\mathrm{II}-\mathrm{V}$ \\
\hline 7. & Bilangan Asli & $\begin{array}{l}\text { Melakukan operasi pembagian bilangan asli } \\
\text { dengan pembagi puluhan }\end{array}$ & III - VI \\
\hline 8. & Bilangan Bulat & $\begin{array}{l}\text { Melakukan operasi penjumlahan yang melibatkan } \\
\text { bilangan bulat positif dan negatif }\end{array}$ & \\
\hline 9. & Bilangan Bulat & $\begin{array}{l}\text { Melakukan operasi penjumlahan yang melibatkan } \\
\text { bilangan bulat negatif dan negatif }\end{array}$ & IV $-V$ \\
\hline 10. & Bilangan Bulat & $\begin{array}{l}\text { Melakukan operasi pengurangan yang melibatkan } \\
\text { bilangan bulat positif dan negatif }\end{array}$ & \\
\hline
\end{tabular}




\begin{tabular}{|c|c|c|c|}
\hline \multirow[b]{2}{*}{ No } & \multirow[b]{2}{*}{ Spesifikasi } & \multicolumn{2}{|l|}{ PDM menurut Kurikulum 2013} \\
\hline & & Indikator & $\begin{array}{l}\text { Kelas } \\
(\mathrm{SD})\end{array}$ \\
\hline 11. & Bilangan Bulat & $\begin{array}{l}\text { Melakukan operasi pengurangan yang melibatkan } \\
\text { bilangan bulat negatif dan negatif }\end{array}$ & \\
\hline 12. & Bilangan Bulat & $\begin{array}{l}\text { Melakukan operasi perkalian yang melibatkan } \\
\text { bilangan bulat negatif dan negatif }\end{array}$ & \\
\hline 13. & Bilangan Bulat & $\begin{array}{l}\text { Melakukan operasi pembagian yang melibatkan } \\
\text { bilangan bulat positif dan negatif }\end{array}$ & \\
\hline 14. & Pecahan & Mendeteksi pecahan senilai & III \\
\hline 15. & Pecahan & Mengurutkan pecahan & IV \\
\hline 16. & Pecahan & $\begin{array}{l}\text { Melakukan operasi penjumlahan pecahan } \\
\text { berpenyebut sama }\end{array}$ & \multirow{4}{*}{ IV } \\
\hline 17. & Pecahan & $\begin{array}{l}\text { Melakukan operasi penjumlahan pecahan } \\
\text { berpenyebut berbeda }\end{array}$ & \\
\hline 18. & Pecahan & $\begin{array}{l}\text { Melakukan operasi pengurangan pecahan } \\
\text { berpenyebut berbeda }\end{array}$ & \\
\hline 19. & Operasi & $\begin{array}{l}\text { Melakukan operasi perkalian terhadap pecahan } \\
\text { dengan bilangan bulat }\end{array}$ & \\
\hline 20. & Pecahan & Melakukan operasi perkalian antara dua pecahan & \multirow{5}{*}{ V } \\
\hline & Operasi & $\begin{array}{l}\text { Melakukan operasi pembagian antara pecahan } \\
\text { dengan bilangan bulat }\end{array}$ & \\
\hline 22. & Operasi & $\begin{array}{l}\text { Melakukan operasi pembagian antara bilangan } \\
\text { bulat dengan pecahan }\end{array}$ & \\
\hline 23. & Pecahan & $\begin{array}{l}\text { Melakukan operasi pembagian antara dua pecahan } \\
\text { dengan pecahan pertama lebih besar dari pecahan } \\
\text { kedua }\end{array}$ & \\
\hline 24. & Pecahan & $\begin{array}{l}\text { Melakukan operasi pembagian antara dua pecahan } \\
\text { dengan pecahan pertama lebih kecil dari pecahan } \\
\text { kedua }\end{array}$ & \\
\hline
\end{tabular}

(Modifikasi dari Kadir, 2010)

Analisis data dalam penelitian ini mengikuti langkah-langkah: (1) reduksi data, yaitu proses mengolah data secara kuantitatif untuk diketahui statistik deskriptif data, persentase kebenaran jawaban dan tingkat kesukaran butir soal; (2) penyajian data, yaitu data tereduksi disajikan melalui penyajian data, data terorganisasikan, tersusun dalam pola hubungan, sehingga akan semakin mudah dipahami; dan, (3) penafsiran dan penarikan kesimpulan, yaitu data yang telah disajikan kemudian ditafsirkan dan disimpulkan (Miles \& Huberman, 1994).

Sebelum direduksi, data hasil penelitian ini dianalisis dengan menggunakan uji validitas dan uji reliabilitas instrumen tes. Validitas instrumen yang diukur adalah validitas empiris berdasarkan data hasil tes PDM siswa dengan menggunakan rumus koefisien korelasi product moment. Berdasarkan analisis menggunakan aplikasi Microsoft Excel diperoleh bahwa semua item tes yang diujikan valid pada taraf $\alpha=0.05$. Ini berarti bahwa instrumen yang diujikan layak digunakan dalam penelitian ini. Koefisien 
relibilitas $\left(r_{i i}\right)$ sebesar 0.846 bermakna bahwa hasil tes PDM dari 30 butir tes tersebut memiliki konsistensi yang sangat tinggi.

\section{Hasil dan Pembahasan}

\subsection{Hasil Penelitian}

Gambaran pengetahuan dasar matematika siswa terkait topik aritmatika dapat dilihat dari pencapaian indikator setiap butir soal. Semakin tinggi pencapaian siswa menunjukkan semakin baiknya pengetahuan siswa terhadap indikator yang diujikan. Pencapaian per-indikator dapat dilihat pada Diagram 1 berikut.

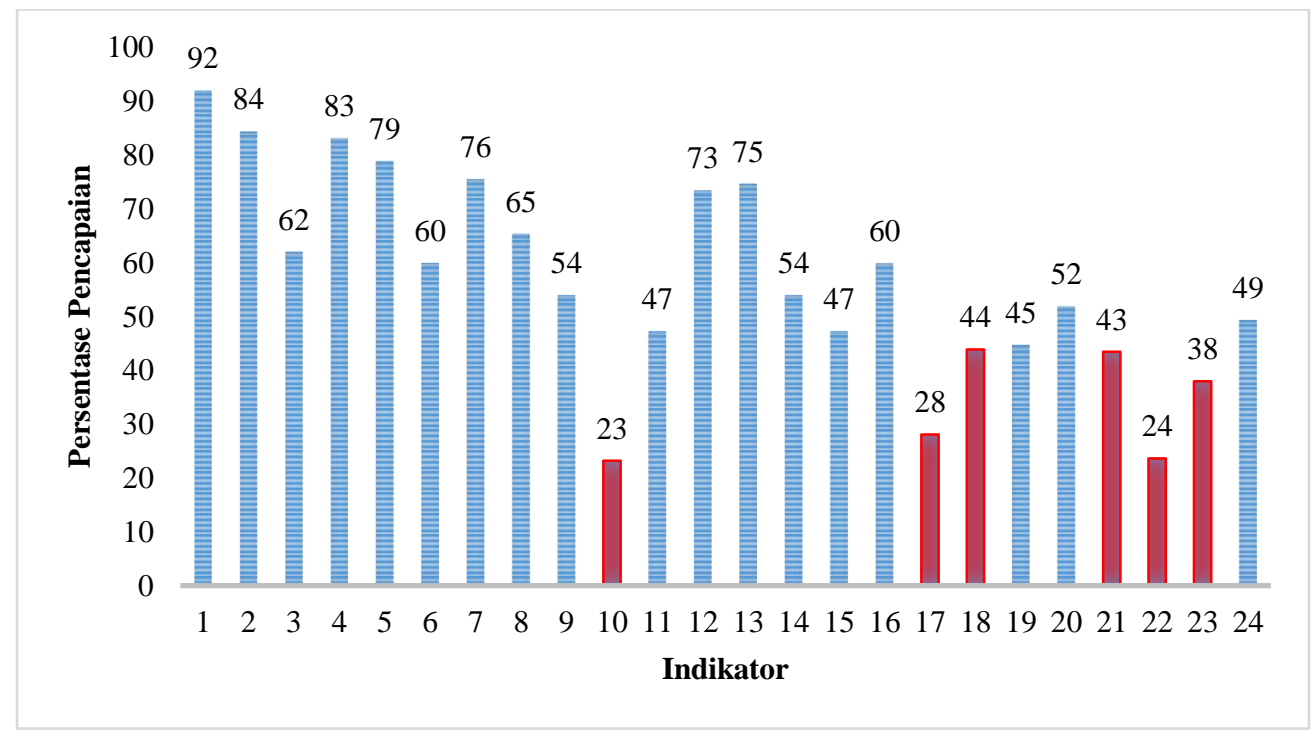

Diagram 1. Pencapaian indikator 1-24 (khusus konsep aritmatika)

Tabel 2. Persentese kesalahan dan miskonepsi pada indikator dengan pencapaian kurang dari $40 \%$

\begin{tabular}{lc}
\hline \multicolumn{1}{c}{ Indikator } & $\begin{array}{c}\text { Persentase } \\
\text { Kesalahan (\%) }\end{array}$ \\
\hline $\begin{array}{l}\text { Melakukan operasi pengurangan yang melibatkan bilangan bulat positif dan } \\
\text { negatif }\end{array}$ & 77 \\
\hline $\begin{array}{l}17 . \\
\text { Melakukan operasi penjumlahan pecahan berpenyebut berbeda }\end{array}$ & 72 \\
\hline \begin{tabular}{l} 
Melakukan operasi pengurangan pecahan dengan penyebut berbeda \\
\hline 21.
\end{tabular} & 56 \\
\hline
\end{tabular}




\begin{tabular}{lc}
\hline Melakukan operasi pembagian antara pecahan dengan bilangan bulat & 76 \\
\hline 22. & 62 \\
Melakukan operasi pembagian antara bilangan bulat dengan pecahan & \\
\hline 23. & \\
Melakukan operasi pembagian antara dua pecahan dengan pecahan pertama & \\
lebih besar dari pecahan kedua &
\end{tabular}

\title{
Tabel 3. Analisis miskonsepsi
}

\section{Operasi pengurangan bilangan bulat}

$25-(-14)=\ldots$.
A. -39
C. 39
B. -11
D. 49

\begin{abstract}
Analisis:
Jawaban soal ini adalah C (39). Siswa pada umumnya menjawab pilihan A (32\%) dan B (42\%). Hanya $23 \%$ siswa yang menjawab benar. Pada saat menyelesaikan soal ini, siswa menjawab dengan dua cara: menggunakan garis bilangan dan penjumlahan bersusun. Kesalahan yang terjadi pada cara pertama adalah: (1) siswa mulai pada angka 25 dan bergerak 14 satuan ke kiri (karena operasi pengurangan) dan berhenti pada angka 11, karena mereka melihat tanda negatif (-) pada angka 14, maka mereka memilih jawaban B; (2) siswa mulai pada angka -14 dan bergerak 25 langkah ke kiri dan berhenti pada angka -39, sehingga mereka memilih jawaban A. Sedangkan pada cara kedua: siswa mengurangkan secara bersusun 14 dari 25 , memperoleh jawaban 11 , tetapi karena tanda negatif (-) pada angka 14 maka mereka memilih jawaban B.
\end{abstract}

\section{Operasi penjumlahan pecahan}

Perkirakan jumlahnya: $\frac{12}{13}+\frac{7}{8}$
A. 1
C. 19
B. 2
D. 21

\begin{abstract}
Analisis:
Jawaban soal ini adalah B (2). Sebanyak $28 \%$ siswa menjawab benar. Mayoritas siswa memilih jawaban A (42\%). Sisanya memilih C (17\%) dan D (13\%). Pada proses penyelesaian, siswa menggunakan aturan penjumlahan pecahan dan beberapa siswa menemukan jawaban $\frac{187}{104}$ yang tidak ada pada pilihan. Ada siswa yang mempertanyakan hal ini dan menganggap bahwa ini adalah soal yang salah.
\end{abstract}

\section{Operasi pengurangan pecahan}

Rina memiliki kain sepanjang 2/3 meter. Jika kain tersebut digunakan sepanjang $3 / 5$ meter, maka sisa kain Rina adalah ... meter
A. $\frac{1}{2}$
C. $\frac{1}{5}$
B. $\frac{1}{3}$
D. $\frac{1}{15}$

Analisis:

Jawaban soal ini adalah C. Sebanyak 44\% siswa menjawab benar. Opsi A dipilih oleh $9 \%$ siswa,opsi B dipilih 10\% siswa, dan opsi D dipilih oleh 37\% siswa. Banyak siswa yang memilik 
opsi D $\left(\frac{1}{15}\right)$ karena keliru memahami cara menyelesaikan penjumlahan dan pengurangan pecahan. Hal ini dipengaruhi oleh cara guru mengajarkan pengurangan dengan melewatkan pemahaman konsep KPK (Kelipatan Persekutuan Terkecil). Disaat akan menentukan penyebut, siswa langsung diajarkan untuk mengalikan penyebut pada pecahan pertama dengan penyebut pada pecahan kedua, dalam hal ini $3 \times 5=15$. Setelah itu, siswa fokus pada pengurangan 2 dan 3 sehingga menghasilkan 1 .

\section{Operasi Pembagian pecahan dengan bilangan bulat}

$\frac{12}{15} \div 4=\cdots$
A. $\frac{1}{15}$
C. $\frac{8}{15}$
B. $\frac{3}{15}$
D. $\frac{48}{15}$

Analisis:

Jawaban soal ini adalah B. Sebanyak 43\% siswa menjawab benar. Opsi A dipilih $17 \%$ siswa, opsi C dipilih 14\%siswa, dan opsi D dipilih 26\% siswa. Pilihan jawaban siswa cukup variatif menunjukkan pengecoh pada soal ini bekerja dengan baik. Namun mayoritas siswa melakukan kesalahan dengan memilih opsi D. Opsi ini dipilih karena siswa melakukan miskonsepsi terhadap proses pembagian pecahan. Siswa menyamakan proses ini dengan proses pada perkalian pecahan. Prosedur yang tepat seperti yang diajarkan saat bangku sekolah dasar adalah, "dibalik dan dikali". Pecahan kedua dibalik, kemudian operasi pembagian diganti menjadi operasi perkalian. $\frac{12}{15} \div 4=\frac{12}{15} \div \frac{4}{1}=\frac{12}{15} \times \frac{1}{4}=\frac{12 \times 1}{15 \times 4}=\frac{12}{60}=\frac{3}{15}$ (Jawaban benar)

Akan tetapi, pada kasus ini, siswa melewatkan prosedur "membalik" pecahan kedua sehingga memperoleh hasil yang tidak tepat.

$\frac{12}{15} \div 4=\frac{12}{15} \div \frac{4}{1}=\frac{12}{15} \times \frac{4}{1}=\frac{12 \times 4}{15 \times 1}=\frac{48}{15}$ (Jawaban keliru yang membaw siswa memilih Opsi D)

\section{Operasi Pembagian bilangan bulat dengan pecahan (pembagian dengan $1 / 2$ )}

$100: \frac{1}{2}=\ldots$
A. 50
C. 150
B. 100
D. 200

\section{Analisis:}

Jawaban soal ini adalah D (200). Siswa pada umumnya menjawab pilihan A. Hanya $24 \%$ siswa yang menjawab benar. Opsi A dipilih 52\% siswa, opsi B dipilih 11\% siswa, dan opsi C dipilih 13\% siswa. Mayoritas siswa memilih opsi A karena melakukan miskonsepsi sebagai berikut.

Siswa menghitung dengan cara:

$100 \div \frac{1}{2}=100 \div \frac{2}{1}=100 \div 2=50$

Sedangkan prosedur yang benar adalah $100 \div \frac{1}{2}=100 \times \frac{2}{1}=100 \times 2=200$.

Miskonsepsi ini terbalik dengan yang terjadi pada masalah sebelumnya. Disini siswa melewatkan "mengali" dimana pada konsep pembagian pecahan, setelah pecahan kedua dibalik, operasi pembagian berubah menjadi invers nya, yaitu perasi perkalian.

\section{Operasi pembagian pecahan}

$\frac{12}{15}: \frac{4}{15}=\ldots$. 

A. 3
C. $\frac{3}{15}$
B. 1
D. $\frac{1}{5}$

\begin{abstract}
Analisis
Jawaban soal ini adalah A (3). Sebanyak 38\% siswa menjawab benar. Opsi B dan D masingmasing dipilih oleh $11 \%$ siswa. Mayoritas memilih opsi C yaitu sebanyak $40 \%$ siswa. Sama seperti dua masalah sebelumnya, siswa memiliki miskonsepsi yang sangat jelas pada pembagian pecahan. Disini, siswa memilih opsi C $\left(\frac{3}{15}\right)$ karena berfokus pada tanda "bagi", dan penyebut yang sama. Siswa menggunakan pengetahuan awal mereka tentang penjumlahan dan pengurangan pecahan, dimana jika dua pecahan memiliki penyebut yang sama, maka pembilanganya langsung dioperasikan dan penyebutnya tetap. Jadi siswa mengerjakan dengan cara:

$\frac{12}{15} \div \frac{4}{15}=\frac{12 \div 4}{15}=\frac{3}{15}$
\end{abstract}

\title{
3.2 Pembahasan
}

Penelitian ini didesain untuk melihat bagaimana pengetahuan dasar matematika siswa yang kemudian akan digunakan sebagai pengetahuan awal dalam mempelajari materi matematika tingkat lanjut. Laporan dari National Mathematics Advisory Panel menggaris bawahi bahwa kelancaran melakukan operasi hitung dasar pada bilangan dalam praktiknya sangat dibutuhkan untuk membangun pemanggilan kembali secara otomatis (automatic recall) faktafakta tentang penjumlahan/pengurangan dan perkalian/pembagian (Kelly, 2008).

Seperti yang ditampilkan pada hasil, dapat dilihat bahwa siswa mengalami miskonsepsi dalam menyelesaikan soal terkait pengurangan bilangan bulat, pengurangan pecahan berpenyebut berbeda, dan pembagian pecahan. Pembahasan dari miskonsepsi yang terjadi dijabarkan sebagai berikut. Tabel 3 bagian pertama menjabarkan analisis moskonsepsi pada operasi pengurangan dua bilangan bulat dengan bilangan kedua adalah bilangan negatif. Siswa melakukan miskonsepsi dengan berfokus pada operasi "pengurangan" sehingga memberikan hasil yang keliru. Temuan ini sejalan dengan hasil dari Fuadiah, dkk. (2016) yang menemukan bahwa siswa sering menemukan masalah ketika melakukan pengurangan dengan bilangan negatif. Selain karena langsung melakukan operasi pengurangan, siswa juga melakukan miskonsepsi dengan menganggap bahwa operasi pengurangan selalu menghasilkan bilangan yang lebih kecil.

Bagian kedua menjabarkan tentang estimasi pada penjumlahan pecahan. Poin pentingnya disini adalah perintah untuk "memperkirakan" pada soal. Siswa telah diajarkan konsep perkiraan atau pembulatan pada kelas 4 SD, tetapi hanya untuk bilangan asli. Pada saat mengajarkan konsep pecahan, guru diyakini tidak menanamkan dengan baik salah satu konsep pecahan yaitu 
pecahan adalah "bagian dari keseluruhan". Konsep ini menjabarkan bahwa pecahan berasal dari memecahkan sesuatu yang utuh. Konsep ini harus menjelaskan bahwa ada potongan pecahan yang ukurannya mendekati satu yang utuh dan ada potongan yang mendekati habis atau dalam hal ini mendekati nol. Hal ini sejalan dengan temuan dari Ciosek dan Samborska (2016) yang menyimpulkan bahwa konsep pecahan sebagai bagian dari keseluruhan tidak diajarkan dengan baik saat siswa duduk di sekolah dasar. Selain itu, Deringöl (2019) juga menemukan bahwa banyak siswa yang mengalami kesulitan dalam memahami konsep ini meskipun ini merupakan konsep yang sangat mendasar tentang pecahan. Jika konsep ini dipahami dengan baik, maka ketika siswa diminta untuk memperkirakan ukuran dari pecahan $\frac{12}{13}$ dia dapat membayangkan ukurannya yang mendekati 1 , sama halnya dengan pecahan $\frac{7}{8}$. Jadi dari soal tersebut siswa akan dapat menjawab pilihan B yaitu dengan memperkirakan bahwa nilai dari $\frac{12}{13}+\frac{7}{8}$ akan mendekati $1+1=2$. Sejalan dengan temuan ini, Deringöl (2019) mengungkapkan bahwa pada saat pecahan diajarkan, representasi dalam bentuk simbol langsung diajarkan tanpa adanya pemahaman konsep tentang simbol tersebut. Hal ini mengakibatkan siswa menganggap pembilang dan penyebut sebagai dua nilai yang terpisah dan tidak memiliki hubungan (Deringöl, 2019; Dhlamini \& Kibirige, 2014).

Pada bagian ketiga dijabarkan miskonsepsi yang terjadi pada pengurangan pecahan. Siswa langsung mengurangi pembilang pada kedua pecahan yang terlibat dan menghitung penyebut secara terpisah. Sejalan dengan hasil ini, Aliustaoğlu, dkk. (2018) menemukan bahwa siswa menunjukkan miskonsepsi dengan menganggap pembilang dan penyebut sebagai dua entitas yang berbeda ketika melakukan penjumlahan dan pengurangan pecahan. Selain itu, siswa juga menggunakan sifat-sifat aritmatika bilangan asli terhadap pecahan. Temuan ini sejalan dengan temuan Nillas (2010) dan Aliustaoğlu, dkk. (2018) bahwa siswa sering menganggap sama konsep pengurangan pada pecahan dengan pengurangan pada bilangan asli.

Soal kelima yang dianalisis menunjukkan masalah yang terjadi ketika siswa diminta untuk membagi dengan $1 / 2$ (setengah). Siswa mengalami miskonsepsi dengan menganggap membagi dengan $1 / 2$ sama dengan membagi dengan 2. Hal ini sejalan dengan temuan dari Nillas (2010) dan Ball (1990). Pembagian dengan pecahan jarang diajarkan secara konseptual pada jenjang sekolah dasar. Umumnya, siswa diajarkan untuk membagi dengan pecahan tanpa memikirkan apa makna dari masalah yang diberikan. Ini berakibat pada kemampuan siswa yang hanya bisa menyelesaikan masalah secara prosedural (Ball, 1990). 
Masalah ini pula yang terjadi pada saat siswa menjawab soal yang ada pada bagian keempat dan keenam dari Tabel 3. Meskipun bagian keempat membahas pembagian pecahan dengan bilangan bulat, siswa melakukan miskonsepsi yang sama ketika bilangan bulat tersebut diubah menjadi bilangan rasional yang ekuivalen. Salah satu prosedur pembagian dengan pecahan yang tersimpan dalam memori siswa adalah dengan membalik pecahan kedua. Mayoritas siswa lupa untuk mengganti operasi pembagian menjadi perkalian ketika pecahan kedua telah dibalik. Siswa hanya mengingat langkah-langkah prosedur yang menyebabkan hilangnya beberapa langkah pada saat ingatan akan operasi pembagian pecahan dipanggil kembali dari memori. Sejalan dengan temuan ini, Aliustaoğlu, dkk. (2018), Ball (1990), Deringöl (2019) dan Nillas (2010) menyimpulkan bahwa pembagian dengan pecahan menjadi salah satu operasi aritmatika yang tidak dipahami siswa secara konseptual.

Pecahan memainkan sebuah peran utama dalam pembelajaran matematika (Siegler, dkk., 2013). Pecahan secara teoritis penting karena pecahan menyaratkan pemahaman yang lebih dalam tentang bilangan dibandingkan dengan apa yang bisa siswa dapatkan dari pengalaman belajar bilangan bulat. Selain itu, pecahan juga penting secara edukatif karena peranannya dalam matematika tingkat lanjut. Beberapa penelitian telah menunjukkan adanya hubungan yang kuat antara pengetahuan awal tentang pecahan dan prestasi matematika siswa (Bailey, dkk., 2012). Penelitian ini dan beberapa penelitian lainnya (Bailey, dkk., 2012; Booth \& Newton, 2012; Siegler, dkk., 2013) menemukan bahwa banyak orang dewasa dan anak-anak memiliki reperesantasi yang lemah terhadap konsep pecahan. Pengetahuan konsep pecahan yang lemah pada saat sekolah dasar mengindikasikan prestasi belajar yang rendah pada pengetahuan aljabar di tingkat sekolah menengah, yang mengontrol hampir seluruh kemampuan kognitif secara umum. Guru matematika pada jenjang tersebut menyimpulkan adanya hubungan yang sangat kuat antara pengetahuan siswa pada materi pecahan dengan kesuksesan mereka pada penguasaan konsep aljabar. Ketika siswa mulai mempelajari fakta matematika, otak mereka akan fokus pada perhitungan dasar. Ketika mereka telah menjadi otomatis terhadap perhitungan dasar, otak mereka dapat fokus pada aspek yang lain seperti mempelajari nilai tempat, desimal, dan pecahan. Menjadi otomatis dengan pengetahuan dasar-aritmatika-akan membebaskan otak untuk fokus pada proses matematika yang lain. Semakin siswa paham akan operasi perhitungan dasar maka akan semakin meningkatkan kemampuan memori dalam menerima informasi matematika baru.

\section{Kesimpulan}


Berdasarkan temuan dalam penelitian ini, dapat disimpulkan bahwa di tingkat siswa SMP masih terjadi miskonsepsi pada masalah arimatika dasar, khususnya pada konsep: (1) pengurangan bilangan bulat; dan, (2) penjumlahan, pengurangan, perkalian dan pembagian pecahan. Guru menginginkan siswanya mampu melakukan matematika (doing math), dan juga mengharapkan mereka memahami matematika yang mereka lakukan. Guru pada umumnya menyatakan bahwa sudah menjadi tugas matematika untuk meningkatkan kompleksitas, pemahaman akan fakta, rumus, dan alogaritma yang akan membantu siswa melanjutkan pengalaman sukses mereka (O'Connell \& SanGiovanni, 2011). Akan tetapi, guru tidak merubah cara pandang mereka tentang pentingnya pengetahuan dasar matematika, meskipun mereka mengetahui bahwa PDM adalah kemampuan mendasar yang mana tanpanya siswa akan melihat permasalahan matematika sederhana menjadi tampak sulit.

Tujuan guru seharusnya adalah menyandingkan antara pemahaman konseptual dan kemampuan untuk bekerja secara otomatis. Otomatis adalah kemampuan siswa untuk dengan mudah mengingat kembali sebuah fakta. Jika siswa sudah menjadi otomatis, mereka akan dengan sukses menempatkan fakta-fakta baru ke dalam memori. Selain itu, pengajaran yang dilakukan seharusnya bertujuan untuk membuat siswa memahami, bukan sekedar mengingat (remember) fakta-fakta metamatika. Meskipun dalam hal ini siswa memiliki keterbatasan tersendiri dalam menerima dan memproses informasi. Model dan pendekatan pembelajaran yang lebih inovatif akan membantu untuk mengatasi permasalahan ini.

\section{Ucapan Terima Kasih}

Ucapan terima kasih kami berikan kepada Dr. Kadir, M.Si selaku pihak yang memfasilitasi awal mula penelitian ini. Terima kasih juga ditujukan kepada para kepala sekolah menengah pertama di Kota Kendari yang telah mengizinkan peneliti melakukan penelitian di sekolah yang mereka pimpin.

\section{Daftar Pustaka}

Aliustaoğlu, F., Tuna, A., \& Biber, A. Ç. (2018). Misconceptions of sixth grade secondary school students on fractions. International Electronic Journal of Elementary Education, 10(5), 591-599. DOI: 10.26822/iejee.2018541308

Bailey, D. H., Hoard, M. K., Nugent, L., \& Geary, D. C. (2012). Competence with fractions predicts gains in mathematics achievement. Journal of Experimental Child Psychology, 113(3), 447-455. DOI: 10.1016/j.jecp.2012.06.004 
Ball, D. L. (1990). Prospective elementary and secondary teachers' understanding of division. Journal for Research in Mathematics Education, 21(2), 132-144.

Bolognese, C., Fellows, S. A., \& Schuhl, S. (2019). Mathematical misconceptions. The Mathematics Teacher, 112(6), 404-405. DOI: 10.5951/mathteacher.112.6.0404

Booth, J. L., \& Newton, K. J. (2012). Fractions: Could they really be the gatekeeper's doorman? Contemporary Educational Psychology, 37(4), 247-253. DOI: 10.1016/j.cedpsych.2012.07.001

Bush, S. B., \& Karp, K. S. (2013). Prerequisite algebra skills and associated misconceptions of middle grade students: A review. Journal of Mathematical Behavior, 32(3), 613-632. DOI: 10.1016/j.jmathb.2013.07.002

Ciosek, M., \& Samborska, M. (2016). A false belief about fractions - What is its source? Journal of Mathematical Behavior, 42, 20-32. DOI: 10.1016/j.jmathb.2016.02.001

Deringöl, Y. (2019). Misconceptions of primary school students about the subject of fractions: Views of primary teachers and primary pre-service teachers. International Journal of Evaluation and Research in Education (IJERE), 8(1), 29. DOI: 10.11591/ijere.v8i1.16290

Deswita, R., \& Kusumah, Y. S. (2018). Peningkatan kemampuan komunikasi matematis siswa melalui model pembelajaran CORE dengan pendekatan scientific. Edumatika: Jurnal Riset Pendidikan Matematika, 1(1), 35. DOI: $10.32939 /$ ejrpm.v1i1.220

Dhlamini, Z. B., \& Kibirige, I. (2014). Grade 9 learners' errors and misconceptions in addition of fractions. Mediterranean Journal of Social Sciences, 5(8), 236-244. DOI: 10.5901/mjss.2014.v5n8p236

Fuadiah, N. F., Suryadi, D., \& Turmudi, T. (2016). Some difficulties in understanding negative numbers faced by students: A qualitative study applied at secondary schools in Indonesia. International Education Studies, 10(1), 24-38. DOI: 10.5539/ies.v10n1p24

Ghazali, N. H. C., \& Zakaria, E. (2011). Students' procedural and conceptual 
understanding of mathematics. Australian Journal of Basic and Applied Sciences, 5(7), 684-691.

Hadi, A. L., Cahyono, E., \& Kadir, K. (2017). Kemampuan calon guru dalam mengajukan soal cerita kontekstual tentang penjumlahan pecahan. Jurnal Pembelajaran Berpikir Matematika (Journal of Mathematics Thinking Learning), 2(2), 33-44.

Herutomo, R. A., \& Saputro, T. E. M. (2014). Analisis kesalahan dan miskonsepsi siswa kelas VIII pada materi aljabar. Edusentris, 1(2), 134145.

Kadir (2010.) Penerapan pembelajaran kontekstual berbasis potensi pesisir sebagai upaya peningkatan kemampuan pemecahan masalah matematik, komunikasi matematik, dan keterampilan sosial siswa SMP. Disertasi tidak dipublikasikan. Universitas Pendidikan Indonesia, Bandung.

Kemendikbud. (2013). Materi pelatihan guru implementasi Kurikulum 2013 SMP/MTs matematika. Jakarta: Kemendikbud.

Kelly, A. E. (2008). Reflections on the national mathematics advisory panel final report. Educational Researcher, 37(9), 561-564.

Koichu, B., Harel, G., \& Manaster, A. (2013). Ways of thinking associated with mathematics teachers' problem posing in the context of division of fractions. Instructional Science, 41(4), 681-698. DOI: 10.1007/s11251012-9254-1

Leinhardt, G., Stein, M. K., \& Zaslavsky, O. (1990). Functions, graphs, and graphing: Tasks, learning, and teaching. Review of Educational Research, 60(1), 1-64. DOI: 10.3102/00346543060001001

Malihatuddarojah, D., \& Prahmana, R. C. I. (2019). Analisis kesalahan siswa dalam menyelesaikan permasalahan operasi bentuk aljabar. Jurnal Pendidikan Matematika, 13(1), 1-8. DOI: 10.22342/jpm.13.1.6668.1-8

Miles, M. B., \& Huberman, A. M. (1994). Qualitative data analysis: An expanded sourcebook. New York: Sage.

Muhsin, Johar, R., Nurlaelah, E. (2013). Peningkatan kemampuan pemahaman dan pemecahan masalah matematis melalui pembelajaran dengan pendekatan kontekstual. Jurnal Peluang, 2(1), 13-24. 
Nillas, L. A. (2010). Fraction operations : Preservice teachers' misconceptions and perceptions about problem-solving. Scholarly Publications, 47, 103124.

O'Connell, S., \& SanGiovanni, J. (2011). Mastering the basic math facts in addition and subtraction. UK: Heinemann.

OECD. (2019). PISA 2018 insights and interpretations. OECD Publishing, 64. Diambil dari https://www.oecd.org/pisa/PISA 2018 Insights and Interpretations FINAL PDF.pdf

Ojose, B. (2015). Students' misconceptions in mathematics: Analysis of remedies and what research says. Ohio Journal of School Matehmatics, $72,30-34$.

Philipp, R. A. (2000). Unpacking a conceptual lesson: The case of dividing fractions. Center for Research in Mathematics and Science Education, San Diego State University: San Diego, CA.

Priyambodo, S. (2016). Peningkatan kemampuan pemahaman konsep matematis siswa dengan metode pembelajaran personalized system of instruction. Mosharafa: Jurnal Pendidikan Matematika, 5(1), 10-17.

Siegler, R. S., Duncan, G. J., Davis-Kean, P. E., Duckworth, K., Claessens, A., Engel, M., Susperreguy, M. I., \& Chen, M. (2012). Early predictors of high school mathematics achievement. Psychological Science, 23(7), 691-697. DOI: 10.1177/0956797612440101

Siegler, R. S., Fazio, L. K., Bailey, D. H., \& Zhou, X. (2013). Fractions: The new frontier for theories of numerical development. Trends in Cognitive Sciences, 17(1), 13-19. DOI: 10.1016/j.tics.2012.11.004

Siegler, R. S., Thompson, C. A., \& Schneider, M. (2011). An integrated theory of whole number and fractions development. Cognitive Psychology, 62(4), 273-296. DOI: 10.1016/j.cogpsych.2011.03.001

Vermeulen, C., \& Meyer, B. (2017). The equal sign: Teachers' knowledge and students' misconceptions. African Journal of Research in Mathematics, Science and Technology Education, 21(2), 136-147. DOI: 10.1080/18117295.2017.1321343 